\title{
Pengaruh Manajemen Keuangan terhadap Kinerja Aparatur Sipil Negara (ASN) pada Bagian Perekonomian dan Pembangunan Setda Kabupaten Tapanuli Tengah
}

\section{Safriadi Pohan}

STIE Al-Washliyah Sibolga

safriadip@gmail.com

Ismael Hutabarat

STIE Al-Washliyah Sibolga

\begin{abstract}
Manajemen keuangan merupakan ilmu dan seni dalam mengelola keuangan yang mempengaruhi instansi dalam pengambilan keputusan,yang biasanya berupa asset yang dibutuhkan dan penggunaan dana seefisien mungkin. Kesuksesan suatu perusahaan atau instansi ditentukan dari kualitas kinerja para aparaturnya.Pada penelitian ini dilakukan beberapa pengujian yang bertujuan untuk mengetahui hubungan dan pengaruh antara penerapan manajemen keuangan terhadap kualitas kinerja Aparatur Sipil Negara.Dari perhitungan koefisien korelasi, untuk melihat hubungannya diperolehsebesar0,89. Hal ini termasuk dalam tingkat korelasi sempurna. Untuk melihat seberapa besar pengaruhnya dilakukan perhitungan koefisien determinasi, dan hasil yang diperoleh sebesar $79 \%$ dan sisanya sebesar $21 \%$ ditentukan oleh variabel-variabel lain yang tidak dibahas dalam penelitian ini, seperti variabel kepemimpinan, kompensasi, sumber daya manusia dan lainlain.Untuk mengetahui apakah hipotesis yang ditawarkan ditolak atau diterima, maka dilakukan uji hipotesis dengan cara membandingkan nilai $t$ hitung dengan nilai $t$ tabel dan hasil yang diperoleh : Nilai $t$ hitung $>$ dari nilai $t$ table $(16,05>0,64)$ ini berarti bahwa hipotesis yang diajukan pada Bab I dapat " diterima “"
\end{abstract}

Keyword Manajemen Keuangan, Kualitas Kinerja, Koefiesien Korelasi 


\section{PENDAHULUAN}

\section{A. Latar Belakang}

Setiap organisasi atau instansi, sudah menyusunperencanaan dengan baik serta adanya sarana prasarana yang mendukung, tetapi apabila tidak didukung oleh Sumber Daya Manusia yang berkompeten dalam ilmu Manajemen, maka instansi tersebut tetap tidak akan bisamencapai tujuan yang diharapkan.

Setiap instansi selalu mempunyai berbagai macam tujuan yang hendak dicapai. Untuk mencapai tujuan organisasi, pimpinan instansi perlu menguasai ilmu manajemen untuk memenej atau mengelola seluruh sumber daya yang ada. Saat ini, figur pemimpin tidak lagi dinilai sebagai tampuk kendali yang mendominasi, melainkan sebagai alat untuk menginspirasi orang lain.

Bila ditinjau dari unsur-unsur manajemen yang dikenal dengan istilah $5 \mathrm{M}$, yaitu : manusia, material, metode, mesin dan money (uang), serta faktor-faktor yang mempengaruhi. Kinerja aparatur pada Bagian Perekonomian dan Pembangunan Setdakab Tap.Tengah sudah cukup baik, namun tidak tertutup kemungkinan kinerjanyamasih tetap kurang berkualitas, padahal citra dan kesuksesan suatu perusahaan/instansi itu ditentukan dari kualitas kinerja para pegawai atau tenaga kerjanya. Atas dasar ini lah penulis ingin meneliti salah satu unsur manajemen yang disebutkan diatas yaitu unsur money/uang.

Manajemen keuanganberhubungan dengan proses, lembaga, pasar dan instrumen yang terlibat dalam transfer uang, di antara individu maupun antara bisnis dan pemerintah. Manajemen keuangan dalam banyak hal juga berpengaruh pada pengambilan keputusan sebuah masalah organisasi perusahaan/instansi. Keputusan yang berkaitan dengan keuangan yaitu berupa asset yang dibutuhkan dan penggunaan dana seefisien mungkin.

Berdasarkan uraian tersebut diatas, maka penulis tertarik untuk melakukan penelitian pada Bagian Perekonomian dan Pembangunan Setdakab Tap.Tengah, dimana penulis ingin mengetahui Pengaruh penerapan Manajemen Keuangan terhadap kualitas kinerja Aparatur Sipil Negara (ASN) pada Bagian Perekonomian dan Pembangunan Sekretariat Daerah Kabupaten Tapanuli Tengah.

\section{TINJAUAN PUSTAKA}

\section{A. Manajemen Keuangan}

Menurut Prawironegoro(2007 : 1), manajemen keuanganadalah aktivitas pemilik dan manajemen perusahaan untuk memperoleh modal yang semurah-murahnya dan menggunakannya seefektif, seefisien dan seproduktif mungkin untuk menghasilkan laba. Adapun aktivitas yang dimaksud adalah sebagai berikut :

1. Aktivitas Pembiayaan (Financing Aktivity)

2. Aktivitas Investasi (Investment Activity)

\section{Aktivitas Bisnis (Business Activity)}

Menurut Brigham dan Houston yang diterjemahkan oleh Dodo, $\mathrm{H}$ dan Herman, W. (2001 ; 6), Manajemen Keuangan merupakan bidang yang terluas dari tiga bidang keuangan, dan memiliki kesempatan karir yang sangat luas. Adapun tiga bidang keuangan yang dimaksud adalah : 
1. Pasar uang dan pasar modal, yang terkait dengan pasar sekuritas dan lembaga keuangan.

2. Investasi, yang memfokuskan pada keputusan yang dibuat oleh investor individual dan intusional dalam memiliki securitas untuk portfolio investasi.

Menurut Jaka, W. dan Kirbrandoko (2002 : 3), manajemen keuanganyaitu : Manajemen dapat dirumuskan oleh fungsi dan tanggung jawab para manajer keuangan. Fungsi pokok manajemen keuangan antara lain menyangkut keputusan tentang penanaman modal, pembiayaan kegiatan usaha dan pembagian deviden pada suatu perusahaan.

\section{B. Kinerja}

Kinerja berasal dari kata job performanceatau actual performance yang berarti prestasi kerja atau prestasi sesungguhnya yang dicapai oleh seseorang. Pengertian kinerja (prestasi kerja) adalah hasil kerja secara kualitas dan kuantitasyang dicapai oleh seseorang pegawai dalam melaksanakan fungsinya sesuai dengan tanggung jawab yang diberikan kepadanya.

Performance atau kinerja merupakan hasil atau keluaran dari suatu proses(Nurlaila, 2010:71) Menurut pendekatan perilaku dalam manajemen, kinerja adalah : Kuantitas atau kualitas sesuatu yang dihasilkan atau jasa yang diberikan oleh seseorang yang melakukan pekerjaan(Luthans, 2005:165).

\section{METODE PENELITIAN}

Instrumen penelitian digunakan untuk mengukur nilai variabel yang akan diteliti. Adapun skala pengukuran untuk nilai variabel adalah menggunakan skala likert. Menurut Sugiyono, (2004 : 86) menyatakan bahwa : Skala likert digunakan untuk mengukur sikap, pendapat, dan persepsi seseorang atau sekelompok orang tentang fenomena sosial.

Dengan menggunakan skala likert, maka variabel yang akan diukur dijabarkan menjadi variabel yang dijadikan sebagai titik tolak ukur untuk menyusun item-item instrumen yang dapat berupa pertanyaan atau pernyataan.

Jawaban setiap item instrumen yang menggunakan skala likert mempunyai gradasi sangat setuju sampai sangat tidak setuju dan setiap jawaban yang diberikan responden akan dinilai seperti berikut :

a. Sangat Setuju diberi skor $=5$

b. Setuju diberi skor $=4$

c. Ragu-ragu diberi skor $=3$

d. Tidak Setuju diberi skor $=2$

e. Sangat Tidak Setuju diberi skor $=1$

Untuk mengklarifikasi dan menginterpresentasikan data berdasarkan nilai tiap-tiap pertanyaan menurut Sugiyono, (2004 : 168) menyatakan bahwa nilai yang diperoleh dapat ditentukan dengan menggunakan interval dengan rumus :

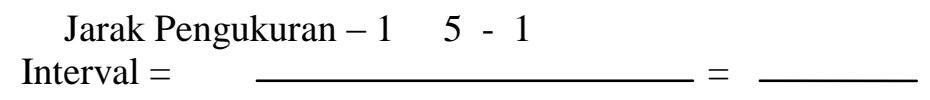


Jumlah Nilai 5

Interval $=0,8$

Dengan interval 0,8 maka skala nilai yang digunaka sebagai berikut:

a. Skala nilai antara 4,2 sampai 5,0 digolongkan dalam kategori Sangat Baik.

b. Skala nilai antara 3,3 sampai 4,1 digolongkan dalam kategori Baik.

c. Skala nilai antara 2,4 sampai 3,2 digolongkan dalam kategori Cukup.

d. Skala nilai antara 1,5 sampai 2,3 digolongkan dalam kategori Kurang Baik.

e. Skala nilai antara 0,6 sampai 1,4 digolongkan dalam kategori Buruk.

\section{HASIL DAN PEMBAHASAN}

Untuk membuktikan hipotesis yang diajukan pada Bab 1 sebelumnya, maka dilakukan dengan melalui 4 tahap pengujian yaitu : koefisien korelasi pearson product momen, koefisien determinan, regresi linear sederhana dan uji $t$. Data angket penelitian variable $\mathrm{X}$ dan variable Y ditabulasikan dalam table penolong,Dimana akan dikalkulasikan jumlah variable $\mathrm{X}, \mathrm{Y}, \mathrm{X}^{2}, \mathrm{Y}^{2}, \mathrm{XY}$ sebagaimana dapat dilihat pada tabel1.

\section{TABEL 1}

Tabel penolong untuk menghitung Pengaruh Penerapan Manajemen Keuangan terhadap Kualitas Kinerja

\begin{tabular}{|c|c|c|c|c|c|}
\hline Responden & $\mathbf{X}$ & $\mathbf{Y}$ & $\mathbf{X 2}$ & Y2 & XY \\
\hline $\mathbf{1}$ & 50 & 49 & 2500 & 2401 & 2450 \\
\hline $\mathbf{2}$ & 50 & 48 & 2500 & 2304 & 2400 \\
\hline $\mathbf{3}$ & 50 & 50 & 2500 & 2500 & 2500 \\
\hline $\mathbf{4}$ & 49 & 45 & 2401 & 2025 & 2205 \\
\hline $\mathbf{5}$ & 41 & 41 & 1681 & 1681 & 1681 \\
\hline $\mathbf{6}$ & 50 & 46 & 2500 & 2116 & 2300 \\
\hline $\mathbf{7}$ & 50 & 45 & 2500 & 2025 & 2250 \\
\hline $\mathbf{8}$ & 50 & 45 & 2500 & 2025 & 2250 \\
\hline $\mathbf{9}$ & 45 & 44 & 2025 & 1936 & 1980 \\
\hline $\mathbf{1 0}$ & 48 & 44 & 2304 & 1936 & 2112 \\
\hline $\mathbf{1 1}$ & 50 & 50 & 2500 & 2500 & 2500 \\
\hline $\mathbf{1 2}$ & 50 & 50 & 2500 & 2500 & 2500 \\
\hline $\mathbf{1 3}$ & 50 & 50 & 2500 & 2500 & 2500 \\
\hline $\mathbf{1 4}$ & 49 & 44 & 2401 & 1936 & 2156 \\
\hline $\mathbf{1 5}$ & 50 & 46 & 2500 & 2116 & 2300 \\
\hline $\mathbf{1 6}$ & 50 & 46 & 2500 & 2116 & 2300 \\
\hline $\mathbf{1 7}$ & 50 & 50 & 2500 & 2500 & 2500 \\
\hline $\mathbf{1 8}$ & 39 & 40 & 1521 & 1600 & 1560 \\
\hline $\mathbf{1 9}$ & 50 & 50 & 2500 & 2500 & 2500 \\
\hline $\mathbf{2 0}$ & 39 & 39 & 1521 & 1521 & 1521 \\
\hline $\mathbf{2 1}$ & 45 & 43 & 2025 & 1849 & 1935 \\
\hline $\mathbf{2 2}$ & 46 & 44 & 2116 & 1936 & 2024 \\
\hline $\mathbf{2 3}$ & 50 & 48 & 2500 & 2304 & 2400 \\
\hline
\end{tabular}




\begin{tabular}{|c|c|c|c|c|c|}
\hline $\mathbf{2 4}$ & 50 & 50 & 2500 & 2500 & 2500 \\
\hline $\mathbf{2 5}$ & 50 & 46 & 2500 & 2116 & 2300 \\
\hline $\mathbf{2 6}$ & 50 & 50 & 2500 & 2500 & 2500 \\
\hline $\mathbf{2 7}$ & 45 & 42 & 2025 & 1764 & 1890 \\
\hline $\mathbf{2 8}$ & 50 & 50 & 2500 & 2500 & 2500 \\
\hline $\mathbf{2 9}$ & 29 & 36 & 729 & 1296 & 972 \\
\hline $\mathbf{3 0}$ & 37 & 39 & 1369 & 1521 & 1443 \\
\hline $\mathbf{3 1}$ & 50 & 50 & 2500 & 2500 & 2500 \\
\hline $\mathbf{3 2}$ & 50 & 50 & 2500 & 2500 & 2500 \\
\hline $\mathbf{3 3}$ & 50 & 50 & 2500 & 2500 & 2500 \\
\hline $\mathbf{3 4}$ & 31 & 37 & 961 & 1369 & 1147 \\
\hline $\mathbf{3 5}$ & 36 & 39 & 1296 & 1521 & 1404 \\
\hline $\mathbf{3 6}$ & 50 & 50 & 2500 & 2500 & 2500 \\
\hline $\mathbf{3 7}$ & 50 & 50 & 2500 & 2500 & 2500 \\
\hline $\mathbf{3 8}$ & 35 & 39 & 1225 & 1521 & 1365 \\
\hline $\mathbf{3 9}$ & 50 & 50 & 2500 & 2500 & 2500 \\
\hline $\mathbf{4 0}$ & 50 & 45 & 2500 & 2025 & 2250 \\
\hline Jumlah & $\mathbf{1 . 8 7 7}$ & $\mathbf{1 . 8 3 0}$ & $\mathbf{8 8 . 1 0 0}$ & $\mathbf{8 4 . 4 6 0}$ & $\mathbf{8 6 . 0 9 5}$ \\
\hline \multicolumn{7}{|c|}{ Sumber : pengelohan data } \\
\hline \multicolumn{7}{|c|}{$\mathbf{\Sigma}$} \\
\hline
\end{tabular}

Dari table diatas, diketahui nilai masing-masing variable adalah:

$$
\begin{array}{ll}
\Sigma \mathrm{X} & : 1.877 \\
\Sigma \mathrm{Y} & : 1.830 \\
\Sigma \mathrm{X}^{2} & : 88.100 \\
\Sigma \mathrm{Y}^{2} & : 84.460 \\
\Sigma \mathrm{XY} & : 86.095 \\
\mathrm{~N} & : 40
\end{array}
$$

Perhitungan koefisien antara variabel $\mathrm{x}$ dan $\mathrm{y}$ dilakukan dengan menggunakan rumus Product Moment sebagai berikut :

$$
\begin{aligned}
& r_{X Y}=\frac{n \sum X Y-\left(\sum X\right)\left(\sum Y\right)}{\sqrt{\left[n\left(\sum X^{2}\right)-\left(\sum X\right)^{2}\right] \cdot\left[n\left(\sum Y^{2}\right)-\left(\sum Y\right)^{2}\right]}} \\
& r_{X Y}=\frac{40 \times 86.095-(1.862) \times(1830)}{\sqrt{\left[40(88.100)-(1862)^{2}\right] \cdot\left[40(84.460)-(1830)^{2}\right]}} \\
& r_{X Y}=\frac{3.443 .800-3.407 .460}{\sqrt{(3.524 .000-3.467 .044) x(3.378 .400)-(3.348 .900)}} \\
& r_{X Y}=\frac{36.340}{\sqrt{56.956 \times 29.500}} \\
& r_{X Y}=\frac{36.340}{40.990,26} \\
& r_{X Y}=0,88655192 \text { atau } 0,89
\end{aligned}
$$


Tingkat Korelasi $=89 \%$

Untuk mengetahui kadar tinggi rendahnya koefisien korelasi, oleh :Narbuko, Cholid dan Abu achmadi (2004).

Koefisien :

$$
\begin{aligned}
& \pm 0,00 \mathrm{~s} / \mathrm{d} 1,00 \rightarrow \text { Menunjukkan tanda positif } \\
& \pm 0,81 \mathrm{~s} / \mathrm{d} 1,00 \rightarrow \text { Korelasi Sempurna } \\
& \pm 0,61 \mathrm{~s} / \mathrm{d} 0,80 \rightarrow \text { Korelasi tinggi } \\
& \pm 0,41 \mathrm{~s} / \mathrm{d} 0,60 \rightarrow \text { Korelasi sedang } \\
& \pm 0,21 \mathrm{~s} / \mathrm{d} \quad 0,40 \rightarrow \text { Korelasi rendah } \\
& \pm 0,00 \mathrm{~s} / \mathrm{d} 0,20 \rightarrow \text { Hampir tidak ada korelasi }
\end{aligned}
$$

Dari perhitungan diatas diperoleh koefisien korelasi positif antara variabel X dan Y adalah korelasi sebesar 0,89 nilai ini termasuk dalam korelasi sempurna, artinya terdapat hubungan yang berbanding lurus antara vaktor Penerapan Manajemen Keuangan (variabel X) dengan Kualitas Kinerja ASN (variabel Y). Selanjutnya untuk melihat hubungan yang signifikan antara variabel $\mathrm{X}$ dengan variabel $\mathrm{Y}$, digunakan syarat regresi linier dengan rumus sebagai berikut :

$\mathrm{Y}=\mathrm{a}+\mathrm{bx}$

$\mathbf{b}=\frac{\mathrm{n} \cdot\left(\sum \mathrm{xy}\right)-\left(\sum \mathrm{x}\right) \cdot\left(\sum \mathrm{y}\right)}{\mathrm{n} \cdot\left(\sum \mathrm{x}^{2}\right)-\left(\sum \mathrm{x}\right)^{2}}$

$\mathrm{b}=\frac{40 .(86.095)-(1.862) \cdot(1.830)}{40 x(88.100)-(1.862)^{2}}$

$\mathrm{b}=\frac{3.443 .800-3.407 .460}{3.524 .000-3.467 .044}$

$\mathrm{b}=\frac{36.340}{56.950}$

$\mathrm{b}=0,63$

$\mathrm{a}=\frac{\sum y-b \cdot \sum x}{n}(4)$

$\mathrm{a}=\frac{1.830-1.173,06}{40}$ 
$\mathrm{a}=\frac{656,94}{40}$

$\mathrm{a}=16,42$

Dengan demikian persamaan garis regresi linier variabel $\mathrm{X}$ dan variabel $\mathrm{Y}$ adalah : $\mathbf{Y}$ $=16,42+0,63 \mathrm{X}$. Kondisi ini menunjukkan antara variabel $\mathrm{X}$ (penerapan Manajemen Keuangan ) dengan variabel Y ( kualitas kinerja ) adalah kearah positif, artinya apabila nilai $X($ Penerapan Manajemen Keuangan $)=$ Nol maka variabel $Y($ Kualitas Kinerja $)=16,42$ dan apabila nilai variabel $X=1$, maka variabel $Y=17,05$.

Untuk mengetahui seberapa besar pengaruh variabel $\mathrm{X}$ terhadap variabel $\mathrm{Y}$ dapat dilakukan dengan menggunakan rumus koefisien determinasi, sebagai berikut :

$$
\begin{aligned}
& \mathrm{Kp}=\mathrm{r}^{2} \times 100 \% \\
& =(0,89)^{2} \times 100 \% \\
& =0,79 \times 100 \%
\end{aligned}
$$

$\mathrm{Kp}=79 \%$

Dari perhitungan tersebut diatas maka besarnya koefisien penelitian atau koefisien determinasi adalah sebesar $79 \%$.

Perubahan variabel terikat (kualitas kinerja) mampu dijelaskan oleh variabel bebas (penerapan Manajemen Keuangan) dan sisanya dipengaruhi oleh faktor lain yang tidak diteliti dalam penelitian ini, seperti faktor kepemimpinan, kompensasi, sumber daya manusia dan lain-lain.

Selanjutnya adalah mencari t hitung dengan tujuan untuk mengetahui apakah hipotesis yang diajukan diterima atau ditolak.

Hipotesis diterima atau ditolak dapat diketahui dengan cara sebagai berikut :

1. Membandingkan antara nilai t hitung dengan nilai t tabel dengan ketentuan :

a) Apabila t hitung lebih besar dari nilai t tabel maka hipotesis alternative (Ha) diterima dan hipotesis 0 (Ho) ditolak.

b) Apabila t hitung lebih kecil dari nilai t tabel maka hipotesis alternative (Ha) ditolak dan hipotesis 0 (Ho) diterima.

2. Mencari nilai derajat kebebasan (dk), dengan $\mathrm{dk}=\mathrm{n}-2$, maka $\mathrm{dk}=40-2=38$

3. Setelah nilai $\mathrm{dk}$ diketahui maka nilai $\mathrm{t}$ tabel untuk $\mathrm{dk}=38$ pada taraf signifikan 0,05 adalah sebesar 2,024

Selanjutnya nilai t hitung menurut Arikunto (2006 : 294) dapat dicari dengan rumus :

$$
\begin{aligned}
& t=\frac{r \sqrt{(\mathrm{n}-2)}}{\sqrt{\left(1-r^{2}\right)}} \\
& t=\frac{0,89 \sqrt{(40-2)}}{\sqrt{\left(1-0,89^{2}\right)}}
\end{aligned}
$$




$$
\begin{gathered}
t=\frac{0,89 \times 6,164}{\sqrt{(1-0,79)}} \\
t=\frac{5,48596}{\sqrt{0,21}} \\
\mathrm{t}=26,12
\end{gathered}
$$

Dari hasil perhitungan tersebut di atas, maka selanjutnya nilai t hitung dibandingkan dengan nilai t tabel, setelah dibandingkan memperoleh hasil bahwa t hitung lebih besar dari $t$ tabel atau 26,12>2,024.

Karena nilai $\mathrm{t}$ hitung lebih besar dari nilai $\mathrm{t}$ tabel maka hipotesis alternatif (Ha) diterima dan hipotesa nol (Ho) ditolak, dengan demikian hipotesis yang diajukan pada Bab-1 dapat "diterima".

\section{KESIMPULAN DAN SARAN}

Berdasarkan penjelasan-penjelasan pada uraian sebelumnya, penulis menarik kesimpulan dan memberikan saran yang dianggap penting sebagai bahan masukan dan pertimbangan pada Bagian Perekonomian dan Pembangunan Sekretariat Daerah Kabupaten Tapanuli Tengah pada masa yang akan datang khususnya mengenai penerapan manajemen keuangan demi untuk meningkatkan kinerja Aparatur Sipil Negara.

\section{A. Kesimpulan}

1. Dari hasil observasi dan wawancara yang penulis lakukan :

a. Sarana dan prasarana yang dimiliki Bagian Perekonomian dan Pembangunan Sekretariat Daerah Kabupaten Tapanuli Tengah sudah lengkap dan memadai untuk menghasilkan kinerja yang berkualitas.

b. Dari jumlah aparatur yang ada sudah memadai untuk melaksanakan tupoksi organisasi, yang mana tugas dan tanggung jawab sudah dibagi menurut bidang dan kompetensi masing-masing.

c. Mengenai penerapan Manajemen Keuangannya sudah berangsur baik, setelah melalui proses-proses perbaikan sistim pengelolaannya.

d. Kinerja Aparatur Sipil Negara pada Bagian Perekonomian dan Pembangunan Sekretariat Daerah kabupaten Tapanuli Tengah sangat terpengaruh terahadap sistim penerapan Manajemen Keuangan tiap- tiap kegiatan.

2. Dari Hasil analisis angket penelitian :

a. Antara penerapan manajemen keuangan terhadap kualitas kinerja aparatur pada Bagian Perekonomian dan Pembangunan Sekretariat Daerah Kabupaten Tapanuli Tengah terdapat hubungan positif yang dapat dibuktikan melalui perhitungan koefisien korelasi dengan hasil korelasi sempurna dan sangat tinggi sebesar $=0,89 \%$

b. Dari hasil perhitungan persamaan garis regresi linier variabel $\mathrm{X}$ dan variabel $\mathrm{Y}$ adalah : $Y=16,05+0,64 X$. Dalam hal ini antara variabel $X$ (Penerapan Manajemen Keuangan) dengan variabel Y (Kualitas Kinerja) adalah ke arah positif, artinya apabila nilai X (Penerapan Manajemen Keuangan) sama dengan nol maka variabel Y (Kualitas Kinerja) sama dengan 16.05, dan apabila variabel $X$ (Penerapan 
Manajemen Keuangan) sama dengan satu, maka variabel Y (Kualitas Kinerja) sama dengan 16,69.

c. Dari perhitungan koefisien determinasi diperoleh angka sebesar 79\%. Perhitungan ini menunjukkan bahwa kualitas kinerja Aparatur dapat dipengaruhi oleh penerapan Manajemen Keuangan sebesar 79\%, sedangkan sisanya sebesar $21 \%$ dipengaruhi oleh faktor lain yang tidak dibahas dalam penelitian ini.

d. Dari uji hipotesis yang dilakukan dan dengan membandingkan antara nilai $t$ hitung dengan nilai $t$ tabel didapat bahwa nilai $t$ hitung lebih besar dari $t$ tabel $(26,12>$ $2,024)$ ini berarti bahwa hipotesis yang diajukan pada Bab I dapat "diterima".

\section{B. Saran}

Dari penelitian yang telah penulis lakukan, maka penulis merasa perlu memberikan saran dan masukan yang berguna untuk pihak instansi pemerintah Bagian Perekonomian dan Pembangunan Setdakab. Tapanuli Tengah, yaitu :

1. Dalam memenej dana-dana setiap kegiatan itu, hendaklah selalu berpedoman kepada Ilmu Manajemen Keuangan yang sesuai referensi kepustakaan.

2. Agar kualitas kinerja pegawai dapat meningkat, hendaknya perlu diadakan rapat koordinasi setiap bulannya sehingga para pegawai dapat bertemu muka langsung untuk saling membicarakan tugas dalam pencapaian tujuan organisasi.

3. Untuk lebih meningkatkan kualitas kinerja pegawai, hendaknya perlu diadakan penambahan sarana prasarana yang lebih canggih seperti sistem pengabsenan dengan menggunakan sensor tangan.

4. Agar kualitas kinerja pegawai dapat meningkat lagi, hendaknya para pegawai diberikan motivasi berupa pemberian kesempatan yang luas untuk mengikuti pendidikan dan pelatihan kerja.

\section{REFERENSI}

Ghozali, Imam, 2005, Aplikasi Analisis Multivariate dengan Program SPPS,Edisi Ketiga, Semarang : Badan Penerbit Universitas Diponegoro

Hadi, S. 2010. Metodology Research, jilid I,II, III, Yogyakarta : Andi Offset

Handoko, T.Hani, 2008, Manajemen Personalia dan Sumber Daya Manusia, Yogyakarta : BPFE

Harahap, Sofyan Syafri, 2011, Sistem Pengawasan Manajemen, Jakarta : Pustaka Quantum

Hasibuan, SP, Malayu, 2010, Manajemen Sumber Daya Manusia, Jakarta: Edisi Revisi, Bumi Aksara 
Kuncoro, M, 2008, Metode Riset untuk Bisnis dan Ekonomi: Bagaimana Meneliti dan Menulis Tesis?, Jakarta: Erlangga

Lubis Ibrahim, 2011, Pengendalian dan Pengawasan Proyek dalam Manajemen, Jakarta :Ghalia Indonesia

Mangkunegara. Anwar Prabu, 2008, Evaluasi Kinerja SDM, Cetakan Keempat, Bandung, PT Refika Aditama

Ranupanjodo Heidrachman dan Husnan Saud, 2009, Sumber Daya Manusia dan Kinerja, Bandung: Ilham Jaya

Soeratno dan Licoln Arsyad2011, Metodologi Penelitian untuk Ekonomi dan Bisnis, Edisi Revisi, Yogyakarta, UPP AMP YKPN

Sugiyono, 2012, Metode Penelitian Bisnis, Cetakan Ketujuh, Bandung: Alfabeta

Umar Husein, 2009, Desain Penelitian MSDM dan Perilaku Karyawan, Jakarta :Raja Grafindo Persada.

Undang-undang No. 12 Tahun 1995 Tentang Pemasyarakatan

Laoli Yohanna, (2016),Wajah Lemabaga Pemasyarakatan Indonesia Saat Ini, http: eprints.ums.ac.id/790/2/jurnal Daya Saing.1.1 pdf. Diakses : 27-07-2016 